Рекомендована д. фрармац. наук, профр. С. О. Васюк

УДК 661.122+547.825

DOI 10.11603/2312-0967.2016.4.7115

\title{
ВИЗНАЧЕННЯ КІЛЬКІСНОГО ВМІСТУ І СУПУТНІХ ДОМІШОК ПРОТІОНАМІДУ МЕТОДОМ ВИСОКОЕФЕКТИВНОЇ РІДИННОЇ ХРОМАТОГРАФІї
}

\author{
Н. Л. Тарасенко, А. Р. Шостак, В. М. Брицун, Н. В. Останіна \\ ДУ «Інститут громадського здоров'я імені О. М. Марзєєва \\ Національної академії медичних наук України», Київ
}

Резюме: з метою оцінки якості здійснено кількісне визначення і контроль супутніх домішок протитуберкульозного препарату II ряду протіонаміду. Дослідження проводились методом обернено-сразової високоесрективної рідинної хроматографії, на спектрофотометричному детекторі, в ізократичному режимі з детектуванням в УФобласті спектра. Кількісне визначення основної речовини зроблено з використанням зовнішнього стандарту. Для встановлення кількості домішок був застосований метод порівняння з розведеним розчином основної речовини. Показано, що за перевіреними параметрами лікарський препарат відповідає вимогам нормативних документів: містить 99,7 \% від заявленої кількості протіонаміду і $\leq$ 0,54 \% домішок.

Ключові слова: протіонамід, таблетки, туберкульоз, препарати II ряду, контроль якості, ВЕРХ, кількісне визначення, супровідні домішки.

Вступ. Туберкульоз - інфрекційне захворювання, яке зумовлено паличкою Коха (Mycobacterium tuberculosis). В доіндустріальну епоху, до винаходу і промислового виробництва ізоніазиду та інших лікарських засобів, туберкульоз забрав мільйони людських життів. У XX столітті, в зв'язку з прогресом медицини, охорони здоров'я та фрармацевтики, у високорозвинутих країнах кількість захворювань на туберкульоз різко зменшилась [8-10].

Проте в Україні кількість інфрікованих громадян стала збільшуватись з 1991 р., а епідемія туберкульозу офріційно зафріксована 31995 р. [4]. Серед європейських країн наша держава займає 2-ге місце за захворюваністю на туберкульоз [5]. Причини такої ситуації полягають в нестабільній економічній та політичній ситуації, наявності значних соціальних проблем та появі нових хіміорезистентних штамів мікобактерій.
Препарати I ряду - основні, характеризуються високою активністю та порівняно низькою токсичністю. Препарати II ряду - резервні. Вони менш ефективні, токсичніші і часто - дорожчі за препарати I ряду. Проте у випадках слабкої дії чи індивідуального несприйняття препаратів I ряду застосовують саме препарати II ряду. Варто зазначити, що пошук нових антимікобактеріальних засобів продовжується й понині $[1,8]$.

Одним з препаратів резервної групи є протіонамід, який пригнічує у мікобактерій синтез пептидів і міколевих кислот та проявляє бактеріостатичну дію.

У промисловості і фрармацевтичних лабораторіях протіонамід 3 отримують окиснювальним алкілуванням 4-нітрилпіридину 1 н-масляною кислотою з подальшим дигідротіонуванням проміжного 4-нітрил-2-пропілпіридину 2 сульсрідом натрію в солянокислому середовищі [6].

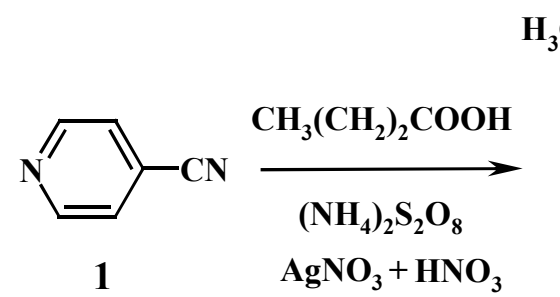

Тому надзвичайно актуальним $є$ ефективне лікування цього захворювання, яке провадиться з застосуванням препаратів I (ізоніазид, рифрампіцин, піразинамід, етамбутол, стрептоміцин) і II рядів (етіонамід, протіонамід, канаміцин, амікацин, ципрофлоксацин, офрлоксацин, циклосерин, капреоміцин, рифрабутин, пара-аміносаліцилова кислота, тіоацетазон) [3].

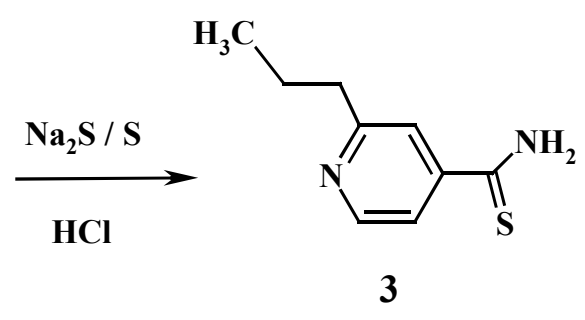

Перша стадія є випадком неузгодженої орієнтації замісників піридинового ядра щодо напрямку електрофрільної реакції. Друга стадія також характеризується наявністю побічних процесів. Крім того, при зберіганні протіонаміду можливий частковий розклад (деградація) діючої речовини. Тому субстанція протіонаміду містить домішки. В роботі [6] хімічну бу-

ISSN 2312-0967. Фармацевтичний часопис. 2016. № 4 
дову деяких із них (сполуки 1-8) було з'ясовано методами спектроскопії ЯМР, ІЧ-спектроскопії та масспектрометрії: фрази 0,5 мл/хв, $\lambda=290$ нм, об'єм інжектування 20 мкл, рухома ораза - фросоратний буфрер : ацетонітрил.<smiles>CCCc1cc(C(N)=O)ccn1</smiles>

1<smiles>CCCc1cc(C#N)cc(CCC)n1</smiles><smiles>CCc1cc(C(N)=S)ccn1</smiles>

7

Ці сполуки мають близьку до протіонаміду молекулярну масу, схожу розчинність і є основними домішками його субстанції та інших лікарських фрорм.

Як і всі лікарські засоби в Україні, протіонамід повинен відповідати стандартам якості, що регламентовані Державною фрармакопеєю України, документами Державного експертного центру МОЗ України і Державної служби України з лікарських засобів та контролю за наркотиками.

Перевірка лікарських засобів в Україні щодо відповідності якісних і кількісних показників виконується в спеціалізованих аналітичних лабораторіях, що мають діючу атестацію та акредитацію [7].

Meта дослідження: встановлення методом високоефективної рідинної хроматографії (BEPX) кількісного вмісту і супутніх домішок таблеток протіонаміду (іноземного виробництва) на предмет відповідності вимогам документації виробника.

Статистичний аналіз отриманих результатів і оцінку невизначеності проводили згідно з вимогами ДФУ (підрозділ 5.3) [2].

Тест придатності хроматограсрічної системи відповідав заявленим вимогам (для 5-ти паралельних інжекцій середнє значення коефіцієнта симетрії піків знаходилось в межах 1,05-1,12, відносне стандартне відхилення площ піків розчину порівняння менше 2,0 \%).

Методи досліджень. Дослідження здійснювали на хроматографрі Agilent 1200 з спектрофротометричним детектором, методом обернено-фразової ВЕРХ в ізократичному режимі з детектуванням в УФ-області спектру.

Використовувалась колонка Zorbax CB-C18 (довжина 150 мм, діаметр 4,6 мм, зерно 3 мкм), температура колонки $25^{\circ} \mathrm{C}$, швидкість рухомої<smiles>CCc1cc(C#N)ccn1</smiles><smiles>CCCc1cc(C(N)=S)cc(CCC)n1</smiles><smiles>CCCc1cnccc1C(N)=S</smiles>

Розчин порівняння для кількісного визначення: вміщують 50,98 мг стандартного зразку протіонаміду в мірну колбу місткістю 100,0 мл, додають 70 мл рухомої фрази, перемішують до розчинення і додають того ж розчинника до мітки. Відбирають 5,0 мл цього розчину і додають рухомої фрази до об'єму 50,0 мл. Концентрація 50,98 мкг/мл.

Випробовуваний розчин для кількісного визначення: 58,4 мг порошку розтертих таблеток протіонаміду всипають в мірну колбу об'ємом 100,0 мл, додають 70 мл рухомої фрази, перемішують до розчинення. Додають того ж розчинника до мітки і фрільтрують. Відбирають 5,0 мл цього розчину і додають рухомої фрази до об'єму 50,0 мл. Приблизна концентрація 50 мкг/мл.

Результати хроматографічнних досліджень порівняльного і випробовуваного розчинів наведено в таблиці 1.

Випробовуваний розчин для визначення супровідних домішок: вміщують 50,98 мг стандартного зразку протіонаміду в мірну колбу місткістю 100,0 мл, додають 70 мл рухомої фрази, перемішують до розчинення, додають того ж розчинника до мітки і перемішують. Концентрація 0,5098 мг/мл.

Еталонний 1 \% розчин протіонаміду для визначення супровідних домішок: вміщують 50,98 мг стандартного зразку протіонаміду в мірну колбу місткістю 100,0 мл, додають 70 мл рухомої фрази, перемішують до розчинення і додають того ж розчинника до мітки. Переносять 1,0 мл вищевказаного розчину в мірну колбу на 100,0 мл, додають того ж розчинника до мітки і перемішують. Концентрація 5,098 мкг/мл.

Результати хроматограсрічних досліджень еталонного і випробовуваного розчинів наведені, відповідно, в таблицях 2 і 3.

ISSN 2312-0967. Pharmaceutical review. 2016. № 4 
Аналіз лікарських препаратів Analysis of drugs

Таблиця 1. Кількісне визначення протіонаміду методом BEPX

\begin{tabular}{|l|c|c|c|c|}
\hline \multirow{2}{*}{ № } & \multicolumn{2}{|c|}{ Розчин порівняння } & \multicolumn{2}{|c|}{ Випробовуваний розчин } \\
\cline { 2 - 5 } & Час утримування, хв & Площа піків & Час утримування, хв & Площа піків \\
\hline 1 & 6,382 & 5771,833 & 6,381 & 5610,879 \\
\hline 2 & 6,377 & 5776,754 & 6,387 & 5607,701 \\
\hline 3 & 6,376 & 5771,754 & 6,376 & 5608,234 \\
\hline 4 & 6,392 & 5769,395 & 6,379 & 5603,352 \\
\hline 5 & 6,367 & 5783,680 & 6,393 & 5622,303 \\
\hline Середнє значення & 6,379 & 5774,683 & 6,383 & 5610,494 \\
\hline Відносне стандартне відхил., \% & 0,14 & 0,10 & 0,11 & 0,13 \\
\hline
\end{tabular}

Таблиця 2. Результати хроматограсрування 1 \% розчину протіонаміду

\begin{tabular}{|c|c|c|c|c|c|}
\hline № & Час утримування, хв & Площа піків & № & Час утримування, хв & Площа піків \\
\hline 1 & 6,386 & 573,142 & 4 & 6,371 & 573,294 \\
\hline 2 & 6,384 & 573,660 & 5 & 6,397 & 572,842 \\
\hline 3 & 6,387 & 575,111 & Середнє & 6,385 & 573,610 \\
\hline & & & Відн.ст. відх.,\% & 0,15 & 0,16 \\
\hline
\end{tabular}

Таблиця 3. Визначення методом ВЕРХ супутніх домішок протіонаміду у випробовуваному розчині

\begin{tabular}{|c|c|c|c|c|c|c|c|}
\hline № & Сполука & $\begin{array}{c}\text { Час утриму- } \\
\text { вання, хв }\end{array}$ & Площа піків & № & Сполука & $\begin{array}{c}\text { Час утриму- } \\
\text { вання, хв }\end{array}$ & Площа піків \\
\hline \multirow[t]{5}{*}{1} & \multirow{3}{*}{$\begin{array}{l}\text { Невідома } \\
\text { домішка } 1\end{array}$} & 2,707 & 50,368 & \multirow[t]{5}{*}{6} & \multirow{3}{*}{$\begin{array}{l}\text { Невідома } \\
\text { домішка } 6\end{array}$} & 5,773 & 148,727 \\
\hline & & 2,702 & 49,772 & & & 5,766 & 148,976 \\
\hline & & 2,702 & 49,686 & & & 5,770 & 148,931 \\
\hline & Середнє & 2,704 & 49,942 & & Середнє & 5,770 & 148,878 \\
\hline & Відн. ст. відх.,\% & 0,11 & 0,74 & & Відн. ст. відх.,\% & 0,06 & 0,09 \\
\hline \multirow[t]{5}{*}{2} & Невідома & 3,749 & 6,245 & \multirow[t]{5}{*}{7} & \multirow[t]{3}{*}{ Протіонамід } & 6,386 & 36453,1 \\
\hline & \multirow{2}{*}{ домішка 2} & 3,741 & 6,548 & & & 6,391 & 36328,8 \\
\hline & & 3,747 & 6,687 & & & 6,408 & 36317,9 \\
\hline & Середнє & 3,746 & 6,493 & & Середнє & 6,395 & 36366,6 \\
\hline & Відн. ст. відх.,\% & 0,11 & 0,23 & & Відн. ст. відх.,\% & 0,18 & 0,21 \\
\hline \multirow[t]{5}{*}{3} & Невідома & 4,185 & 16,283 & \multirow[t]{5}{*}{8} & \multirow{3}{*}{$\begin{array}{l}\text { Невідома } \\
\text { домішка } 7\end{array}$} & 11,939 & 3,573 \\
\hline & \multirow{2}{*}{ домішка 3} & 4,179 & 16,368 & & & 12,001 & 3,511 \\
\hline & & 4,181 & 16,639 & & & 11,921 & 3,534 \\
\hline & Середнє & 4,182 & 16,430 & & Середнє & 11,954 & 3,539 \\
\hline & Відн. ст. відх.,\% & 0,07 & 1,13 & & Відн. ст. відх.,\% & 0,35 & 0,89 \\
\hline \multirow[t]{5}{*}{4} & Невідома & 4,807 & 3,594 & \multirow[t]{5}{*}{9} & \multirow{3}{*}{$\begin{array}{l}\text { Невідома } \\
\text { домішка } 8\end{array}$} & 21,385 & 7,828 \\
\hline & \multirow[t]{2}{*}{ домішка 4} & 4,805 & 3,607 & & & 21,457 & 7,596 \\
\hline & & 4,808 & 3,636 & & & 21,363 & 7,678 \\
\hline & Середнє & 4,807 & 3,612 & & Середнє & 21,402 & 7,701 \\
\hline & Відн. ст. відх.,\% & 0,03 & 0,60 & & Відн. ст. відх.,\% & 0,23 & 1,53 \\
\hline \multirow[t]{5}{*}{5} & \multirow{3}{*}{$\begin{array}{l}\text { Невідома } \\
\text { домішка } 5\end{array}$} & 5,208 & 74,202 & & \multirow{3}{*}{-} & - & - \\
\hline & & 5,201 & 74,046 & & & - & - \\
\hline & & 5,203 & 73,807 & & & - & - \\
\hline & Середнє & 5,204 & 74,018 & & - & - & - \\
\hline & Відн. ст. відх.,\% & 0,07 & 0,27 & & - & - & - \\
\hline
\end{tabular}

Примітка: коефіцієнт симетрії піків на хроматограмах 1,02-1,18.

ISSN 2312-0967. Фармацевтичний часопис. 2016. № 4 
Результати й обговорення. Кількісне визначення проводили методом зовнішнього стандарту [2]: розчин порівняння і випробовуваний розчини поперемінно хроматограсрували і розраховували середні значення площ піків протіонаміду (див. табл. 1).

Заявлена кількість протіонаміду у таблетці 250 мг, нормування протягом терміну придатності 92,5-107,5 \% від заявленої кількості (тобто 231,25268,75 мг). лою:

Вміст протіонаміду (мг) обчислювали за фрорму-

$$
\mathrm{C}_{\text {прот }}=\left(\mathrm{S}_{\text {випр }} \times \mathrm{m}_{\text {ст }} \times \mathrm{A}_{\mathrm{T}} \times \mathrm{P}\right) /\left(\mathrm{S}_{\text {пор }} \times \mathrm{T}\right) \text {, }
$$

де $\mathrm{S}_{\text {випроб }}$ - середня площа піка протіонаміду на хроматограмі випробовуваного розчину, $m_{\text {ст }}$ - наважка стандартного зразка протіонаміду (мг), $\mathrm{A}_{\mathrm{T}}-\mathrm{ce}$ редня маса таблеток (296,12 мг), Р - чистота стандартного зразка $(0,992), \mathrm{S}_{\text {пор }}$ - середня площа піка протіонаміду на хроматограмі розчину порівняння, Т після чого обчислювався вміст домішок. Результати випробовувань наведені в таблицях 2 і 3, а хроматограма досліджуваного розчину протіонаміду відображена на рисунку 1.

Для досліджуваних таблеток протіонаміду виробником були встановлені вимоги щодо вмісту супутніх домішок - не більше 1,0% (індивідуальної домішки не більше 0,5 \%).

Загальну кількість домішок рахували за фрормулою:

$$
\%_{\text {доміш }}=\mathrm{S}_{\text {дом }} / \mathrm{S}_{\text {пор }} \text {, }
$$

де $\mathrm{S}_{\text {дом }}$ - сумарна площа піків домішок на хроматограмі випробовуваного розчину, $\mathrm{S}_{\text {пор }}$ - середня площа піка протіонаміду на хроматограмі 1 \% порівняльного розчину.

Розрахунок з використанням даних таблиць 2, 3 демонструє, що сумарний вміст домішок 1-8 в лікарському засобі складає 0,54 \%, тобто відповідає вимогам нормативних документів.

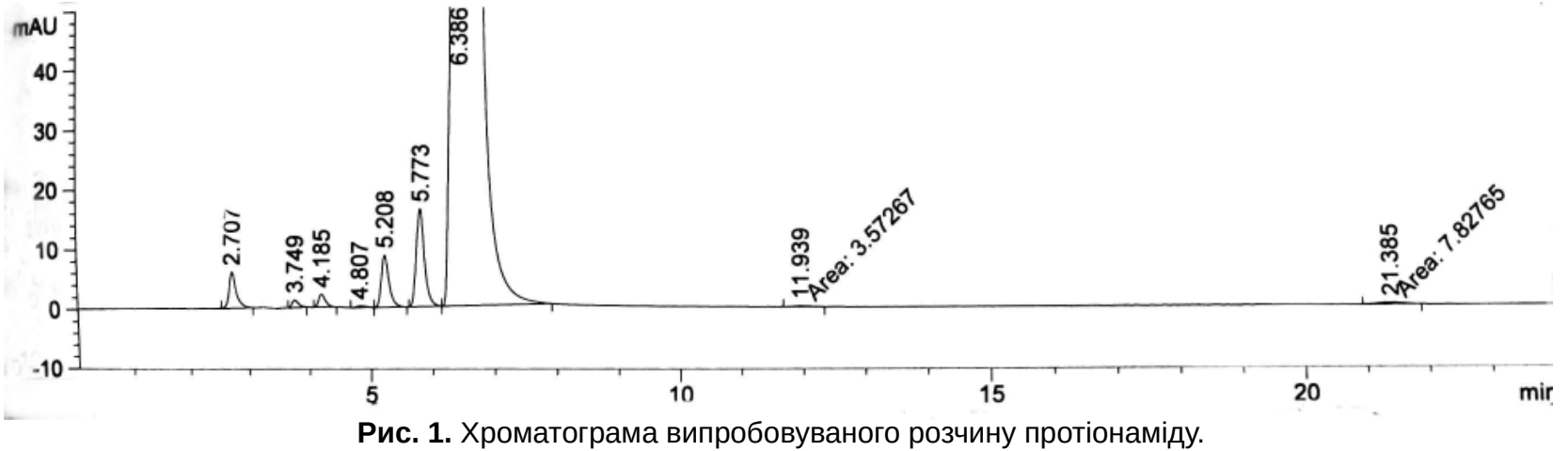

- наважка порошку розтертих таблеток протіонаміду (58,4 мг).

Розрахунок із використанням цифрових даних таблиці 1 і експериментальної частини показує, що $\mathrm{C}_{\text {прот }}=249,14$ мг (99,7\% від заявленої кількості), тобто вміст діючої речовини в лікарському засобі відповідає вимогам нормативних документів.

Визначення супутніх домішок здійснювали методом порівняння з розведеним $1 \%$ розчином основної речовини: інжектувались еталонний та випробовуваний розчини, інтегрувались піки на хроматограмах,

\section{Список літератури}

1. Брицун В. Н. Противотуберкулезные свойства производных имидазола и бензимидазола / В. Н. Брицун, П. А. Карпов, А. И. Емец, М. О. Лозинский // Журн. орг. та фрарм. хімії. - 2011. - Т. 9. - Вип. 3(35). - С. 3-14.

2. Державна Фармакопея України, Т. 1. - Харків «Український науковий фрармакопейний центр якості лікарських засобів», 2015. - 1128 с.

3. Страчунский Л. С. Практическое руководство по антиинфекционной химиотерапии / Л. С. Страчунский, Ю. Б. Белоусов, С. Н. Козлов. - Смоленск : НИИАХ СГМА, 2007. -464 C.
Висновки. Використання запропонованої схеми дослідження дає можливість кількісно визначити активний фармацевтичний інгредієнт і домішки у таблетках протіонаміду. Метод забезпечує високу точність, відтворюваність і селективність аналізу.

Перевірка методом ВЕРХ лікарського засобу протіонаміду в таблетках щодо кількісного вмісту діючої речовини і супутніх домішок показала, що препарат відповідає вимогам нормативної документації і $€$ безпечним для споживачів.

4. Фещенко Ю. І. Епідеміологія туберкульозу у світі / Ю. І. Фещенко, В. М. Мельник, В.Г. Матусевич, Л.Ф. Антоненко // Укр. пульмонол. журнал. - 2003. - № 4. - С. 5-10. 5. Шелепко С. Туберкульоз в Україні / С. Шелепко // Еженедельник Аптека. - 2015. - № 12. - С. 983. http:// www.apteka.ua/article/327618

6. Synthesis and characterization of process related impurities of an antituberculosis drug-Prothionamide / K. C. Eadara, S. R. Divvela, S. B. Sawant, S.W. Gohada // Der Pharm. Chem. - 2015. - Vol.7(3). - P.79-84.

7. http://www.druglab.kiev.ua/

ISSN 2312-0967. Pharmaceutical review. 2016. № 4 
8. Janin Y. L. Antituberculosis drugs: ten years of research / Y. L. Janin // Bioorg. Med. Chem. - 2007. - Vol.15(7). P. 479-2513.

9. Khairnar H. K. A review on: antituberculosis agents /

H. K. Khairnar, R. J. Oswa, R. V. Antre // J. Pharm. Sci.
Bios. Res. - 2012. - Vol. 2(2). - P. 40-48.

10. Zumla A. Advances in the development of new tuberculosis drugs and treatment regimens / A. Zumla, P. Nahid, S. T. Cole // Nature Reviews Drug Discovery. 2013. - Vol. 12. - P. 388-404.

\title{
ОПРЕДЕЛЕНИЕ КОЛИЧЕСТВЕННОГО СОДЕРЖАНИЯ И СОПУТСТВУЮЩИХ ПРИМЕСЕЙ ПРОТИОНАМИДА МЕТОДОМ ВЫСОКОЭФФЕКТИВНОЙ ЖИДКОСТНОЙ ХРОМАТОГРАФИИ
}

\author{
Н. Л. Тарасенко, А. Р. Шостак, В. Н. Брицун, Н. В. Останина \\ ГУ «Институт общественного здоровья имени О. М. Марзеева Национальной академии \\ медицинских наук Украины», Киев
}

Резюме: с целью оценки качества проведено количественное определение и контроль сопутствующих примесей противотуберкулезного препарата II ряда протионамида. Исследования проводились методом обращенно-фразовой высокоэффективной жидкостной хроматографии, на спектрофотометрическом детекторе, в изократическом режиме с детектированием в УФ-области спектра. Количественное определение основного вещества сделано с использованием внешнего стандарта. Для установления количества примесей использовался метод сравнения с разбавленным раствором основного вещества. Показано, что по проверенным параметрам лекарственное средство соответствует требованиям нормативных документов: содержит 99,7 \% от заявленного количества протионамида и $\leq 0,54 \%$ примесей.

Ключевые слова: протионамид, таблетки, туберкулез, препараты II ряда, контроль качества, ВЭЖХ, количественное определение, сопутствующие примеси.

\section{RESEARCH BY HPLC METHOD THE QUANTITATIVE CONTENT AND RELATED IMPURITIES OF PROTHIONAMIDE}

\author{
N. L. Tarasenko, A. R. Shostak, V. M. Britsun, N. V. Ostanina \\ O. Marzieyev Institute for Public Health of the National Academy of Medical Sciences of Ukraine, Kyiv
}

\begin{abstract}
Summary: protionamid is anti-tuberculosis second line drug. The goal of this work is quantitative determination of the active pharmaceutical ingredient (API) and its related substances in some prothionamide tablets. Investigation was carried out by means of reversed-phase HPLC in isocratic mode with spectrophotometric detector in UV-region of spectrum. Quantitative determination of the API was made by using the external standard method. A dilute solution of the API was used to determine the amount of impurities. It is shown that the medical product complie with spesified parameters of the normative documents: it contains $99.7 \%$ of the declared quantity and the sum identified and not identified impurities $\leq 0.54 \%$.
\end{abstract}

Key words: prothionamide, tablets, quality control, tuberculosis, HPLC, quantitative determination, related impurities. 